\title{
CHẢY MÁU TIÊU HÓA DO UNG THƯ NGUYÊN BÀO NUÔI Ở NAM GIỚl: NHÂN MỌT TRƯỜNG HỢP VÀ ĐIỂM LẠI Y VĂN
}

Trần Bảo Long, Nguyễn Hoàng, Nguyễn Hữu Tú, Đào Thị Luận và Nguyễn Đăng Hưng Bệnh viện Đại học Y Hà Nội Trường Đại học Y Hà Nội

Ung thư nguyên bào nuôi ở ống tiêu hóa là một bệnh ung thư rất hiếm gặp ở nam giới. Chẩn đoán khó khăn, kết quả điều trị còn hạn chế. Nhân một trường hợp ung thư nguyên bào nuôi ở ống tiêu hóa của bệnh nhân nam 84 tuổi đã di căn nhiều cơ quan, vào viện mổ 2 lần cấp cứu vì xuất huyết tiêu hóa nặng trong một khoảng thời gian ngắn, lần cuối nhập viện vì xuất huyết não do tổ chức u di căn chảy máu với tiên lượng rất nặng, chúng tôi trình bày bệnh án và điểm lại y văn về bệnh lý hiếm gặp này.

Từ khóa: ung thư nguyên bào nuôi, ống tiêu hóa, nam giới.

\section{I. ĐẠT VẤN ĐỀ}

Ung thư nguyên bào nuôi còn gọi là choriocarcinoma ở ống tiêu hóa là một bệnh lý rất hiếm gặp. Ung thư nguyên bào nuôi ở dạ dày chiếm khoảng $0,08 \%$ các loại ung thư dạ dày ${ }^{1}$, trong đó, hầu hết có thành phần ung thư biểu mô tuyến (adenocarcinoma) ở các mức độ khác nhau. Chẩn đoán trước mổ ung thư nguyên bào nuôi thường khó khăn vì bệnh hiếm gặp đặc biệt ở nam giới, các triệu chứng không đặc hiệu. Vì vậy, kết quả điều trị cũng còn hạn chế. Nhân một trường hợp được chẩn đoán và phẫu thuật vì chảy máu tiêu hóa do khối ung thư nguyên bào nuôi ở dạ dày và ruột non ở bệnh nhân nam 84 tuổi. Chúng tôi xin mô tả đặc điểm bệnh học của trường hợp hiếm gặp này và điểm lại y văn trong chẩn đoán và điều trị.

\section{GIÓ'I THIÊU CA BẸNH}

Bệnh nhân Phạm Ngọc G 84 tuổi. Địa chỉ: Thái Hà - Láng Hạ - Đống Đa - Hà Nội. Vào viện 19/10/2019,vì nôn máu và ỉa phân đen. Bệnh nhân có tiền sử tai biến mạch máu não, điều trị tăng huyết áp và đái tháo đường nhiều năm, bị mệt mỏi từ nhiều tháng đã được chẩn đoán ung thư dạ dày đã di căn gan, phổi, não tại Bệnh viện Đại học Y Hà Nội.
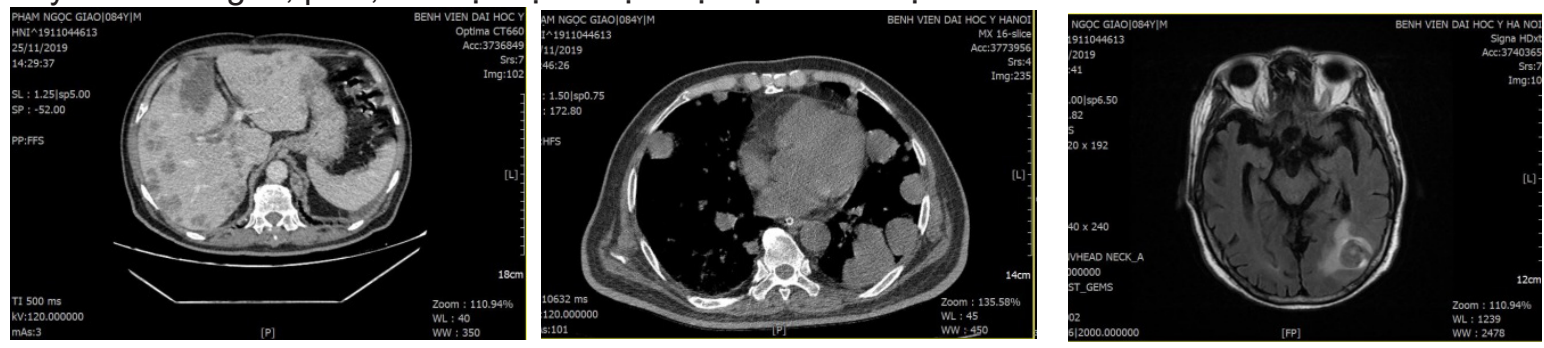

Hình 1. Hình 1. Hình ảnh tổn thương trên

Tác giả liên hệ: Nguyễn Đăng Hưng,

Trường Đại học Y Hà Nội

Email: danghung@hmu.edu.vn

Ngày nhận: 06/06/2021

Ngày được chấp nhận: 02/07/2021 phim CT Scanner ổ bụng ngày 21/10/2019: Dạ dày thành dày không đều, sau tiêm ngấm thuốc mạnh, nhu mô gan có nhiều khối giảm tỷ trọng trước tiêm, ngấm thuốc mạnh thì động mạch thải thuốc thì 
tĩnh mạch, hạch ổ .Lát cắt qua lồng ngực thấy nhiều khối, nốt ngấm thuốc sau tiêm.

Ngày 18/10, bệnh nhân bị nôn máu đỏ và đi ngoài phân đen nhiều lần, được đưa vào Bệnh viện ĐHY Hà Nội trong tình trạng: Tỉnh, da niêm mạc nhợt, mạch 95 lần/phút, thở 18 lần/ phút, huyết áp 110/80mmHg. Xét nghiệm hồng cầu $3.68 \mathrm{~T} / \mathrm{L}, \mathrm{Hb} 85 \mathrm{~g} / \mathrm{L}$, hematocrit $0,29 \mathrm{~L} / \mathrm{L}$; bạch cầu 10,17 G/L; PT 91\%. Nhóm máu $B$, Rh (+). Bệnh nhân được soi dạ dày ngày 21/10/2019 thấy vùng thân vị phía bờ cong lớn có tổn thương lồi $2,5 \mathrm{~cm}$ bề mặt có máu đông bám, không quan sát thấy điểm chảy máu hay điểm mạch. Niêm mạc hang vị nhạt màu có trợt loét nông. Thực quản, tâm vị, hành tá tràng và tá tràng bình thường không có máu. CT Scanner ổ bụng ngày 21/10/2019: Dạ dày bờ cong lớn vùng thân vị thành dày không đều, chỗ dày nhất $22 \mathrm{~mm}$ trên đoạn dài $90 \mathrm{~mm}$ sau tiêm ngấm thuốc mạnh, không thâm nhiễm mỡ xung quanh. Gan biến đổi hình thái, bờ không đều, nhu mô gan có nhiều khối giảm tỷ trọng trước tiêm, ngấm thuốc mạnh thì động mạch thải thuốc thì tĩnh mạch, hạch ổ bụng mạc treo và sau tụy to nhất $25 \times 31 \mathrm{~mm}$. Lát cắt qua lồng ngực thấy nhiều khối, nốt ngấm thuốc sau tiêm.

Kết luận: Hình ảnh dày thành dạ dày bờ cong lớn, các khối tổn thương thứ phát gan, phổi, hạch ổ bụng.

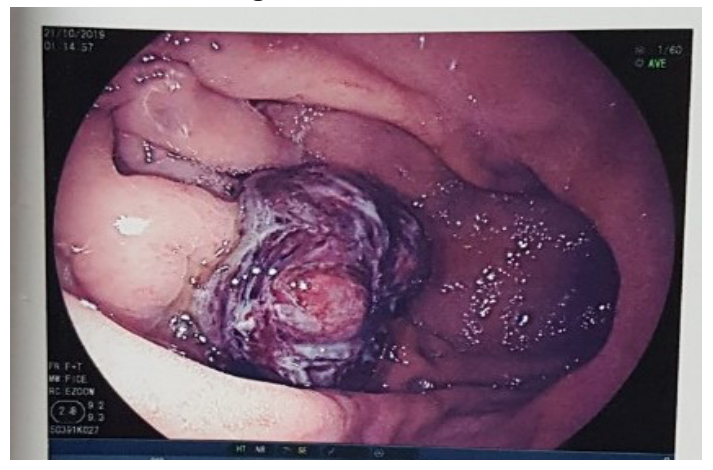

Hình 2. Tổn thương u ở dạ dày trên nội soi
Bệnh nhân được truyền 6 đơn vị máu, điều trị Nexium 40 mg x 2 ống tĩnh mạch/ngày, dung dịch glucoza $5 \%$, Natriclorua $0,9 \%$... nhưng không có kết quả, bệnh nhân vẫn đại tiện phân đen nhiều lần và xét nghiệm số lượng hồng cầu, huyết sắc tố, hematocrit tiếp tục giảm. Ngày 24/10/2019 bệnh nhân được mổ với chẩn đoán chảy máu tiêu hóa do $U$ dạ dày đã di căn gan, phổi, não trên nền di chứng tai biến mạch não do tăng huyết áp và đái tháo đường. Kiểm tra ổ bụng có dịch tiết, gan có nhiều khối di căn gồ ghề trên bề mặt, sinh thiết 1 khối u gan. Vùng phình vị lớn dạ dày có khối u 2 × $2 \mathrm{~cm}$ mật độ chắc không xâm lấn xung quanh, phúc mạc nhẵn không có di căn phúc mạc. Mở dạ dày thấy dịch máu đen loãng, khối u đẩy lồi vào lòng dạ dày, bề mặt xung huyết mạnh. Tiến hành cắt dạ dày hình chêm kèm khối $u$, sinh thiết tức thì diện cắt không có tế bào ác tính. Sau mổ, tình trạng huyết động ổn định, các chỉ số hồng cầu, $\mathrm{Hb}$, Hematocrit tăng dần.

Giải phẫu bệnh: Bệnh phẩm dạ dày $\mathrm{BV}$ 19538 - 19 (30/10/2019). Đại thể: Bệnh phẩm có phù niêm mạc, hình tròn, đường kính $5 \mathrm{~cm}$, đường giữa niêm mạc có u dạng lồi 2 × 2 × $1 \mathrm{~cm}$ cắt qua nâu mềm. Vi thể: u xuất phát từ niêm mạc, phát triển xâm lấn tầng cơ gây hoại tử chảy máu rộng nhu mô dạ dày. U gồm các tế bào hình đa diện đơn nhân dạng đơn bào nôi đứng thành đám xen lẫn các hợp bào khổng lồ nhiều nhân. Tế bào u có nhân lớn, kiềm tính, tỷ lệ nhân/ bào tương tăng, sắp xếp mất cực tính. $U$ xâm nhập mạch máu nhiều vùng. Kết luận: U ác tính hướng tới choriocarcinoma. Kết quả sinh thiết gan trong mổ (BV19539 - 19 ngày 30/10/2019): $U$ ác tính hướng tới Choriocarcinaoma di căn gan. Kết quả hóa mô miễn dịch tiếp theo khẳng định ung thư nguyên bào nuôi. 


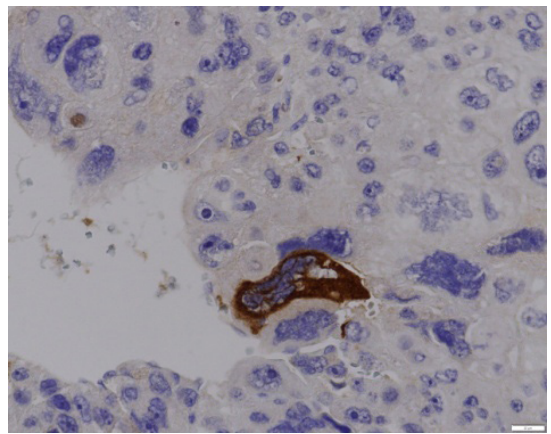

Hình 3. Tổn thương vi thể ở dạ dày (nhuộm HE)

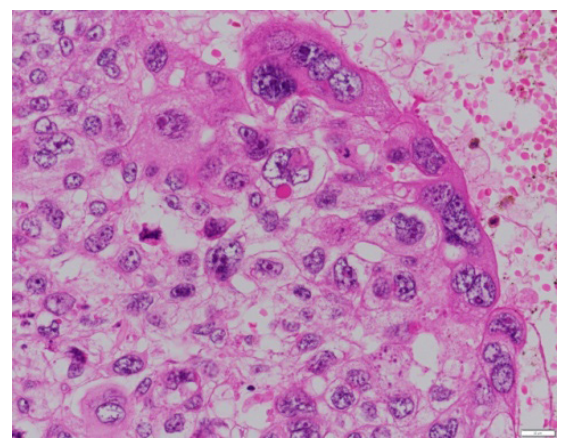

Hình 4. Hóa mô miễn dịch: hợp bào nuôi (+) $\beta$ HCG

Siêu âm (4/11/2019) cho thấy không có khối u nguyên phát ở tinh hoàn. Tinh hoàn phải 31 x $22 \times 16 \mathrm{~mm}$, tinh hoàn trái $36 \times 23 \times 21 \mathrm{~mm}$. Nhu mô đồng nhất, không có khối bất thường, tưới máu đều, tràn dịch màng tinh hoàn 2 bên tương ứng dày 13 và $24 \mathrm{~mm}$.

Xét nghiệm máu $\beta$ HCG (human chorionic gonadotropins) toàn phần ngày 4/11/2019 cho thấy tăng tới 21,2 mIU/mL (bình thường < 2).

Vào ngày thứ 5 sau mổ, bệnh nhân xuát hiện đại tiện phân đen và xét nghiệm các chỉ số hồng cầu, huyết sắc tố, hematocrit lại giảm đi. Soi đại tràng 6/11/2019, đèn soi vào tới manh tràng và $30 \mathrm{~cm}$ hồi tràng thấy khối u chiếm gần hết lòng hồi tràng, nghi ngờ u chảy máu, bơm $10 \mathrm{ml}$ adrenalin 1/1000000. Lòng đại tràng nhiều dịch máu đen cũ hạn chế quan sát, phần quan sát được không có tổn thương. Bệnh nhân được điều trị hồi sức truyền máu, theo dõi sát huyết động và tình trạng chảy máu tiêu hóa không cải thiện, quyết định mổ cấp cứu với chẩn đoán chảy máu tiêu hóa do u ruột non. Kiểm tra trong ổ bụng không có dịch, phúc mạc nhẵn không có di căn phúc mạc, các quai ruột non giãn to chứa máu đen và có 1 khối u đường kính khoảng 2,5 $\mathrm{cm}$ cách góc Treizt khoảng 40 cm, 1 khối kích thước khoảng 4x5 cm cách góc hồi manh tràng khoảng $20 \mathrm{~cm}$. Các phần ruột còn lại không sờ thấy $u$. Tiến hành cắt u phía trên hình chêm và đoạn ruột có u phía dưới.

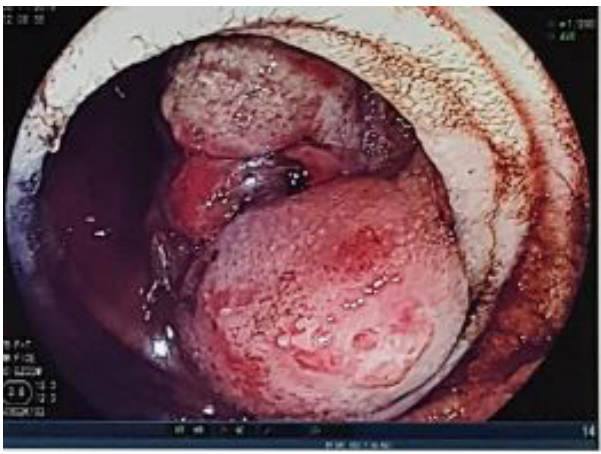

\section{Hình 5. Tổn thương u ở ruột non qua nội soi tiêu hóa}

Sau mổ điều trị giảm đau ngoài màng cứng, kháng sinh Meronem 3g/ngày, truyền máu, huyết thanh và nuôi dưỡng đường tĩnh mạch. Bệnh nhân tiến triển thuận lợi, ra viện ngày 20/11/2019.

Giải phẫu bệnh BV20619 - 19 (13/11/2019). Đại thể: đoạn ruột dài $5,5 \mathrm{~cm}$ có $1 \mathrm{u}$ sùi trên diện $3 \times 2 \mathrm{~cm}$, cắt qua hồng mềm gây co kéo thanh mạc tương ứng kèm 01 bệnh phẩm rời kích thước $1,7 \times 1,2 \times 1 \mathrm{~cm}$, có phù niêm mạc, cắt qua xám nâu hơi chắc. Vi thể: mô ruột có u xuất phát từ niêm mạc xâm lấn tầng cơ gây hoại tử chảy máu rộng. Mô u gồm các tế bào biểu mô nhân lớn, kiềm tính, chất nhiêm sắc thô, hạt nhân rõ, sắp xếp thành đám hay gợi cấu trúc tuyến, bên cạnh đó thấy vùng các tế bào đa diện đơn nhân dạng đơn bào nuôi đứng 
thành đám xen lẫn các hợp bào khổng lồ nhiều nhân, u xâm nhập mạch máu nhiều vùng.

Kết luận: Hình ảnh ung thư tuyến kém biệt hóa có thành phần ung thư biểu mô nguyên bào nuôi di căn thành ruột xâm nhập nhiều mạch máu.

Bệnh nhân vào viện lại ngày 23/11/2019 vì mệt, lơ mơ, Glasgow 10 đ, hồng cầu 2,71T/L, $\mathrm{Hb} 70 \mathrm{~g} / \mathrm{L}$, hematocrit 0,23L/, LPT $59 \%$, INR 1,34. Liệt nửa người phải.

Chụp cộng hưởng từ sọ não có tiêm chất tương phản (25/11/2019): Hình ảnh các khối máu tụ kèm phần tổ chức ngấm thuốc kém bên trong vị trí nhu mô thùy trán và chẩm trái - theo dõi tổn thương thứ phát chảy máu. Các ổ chảy máu nhỏ cạnh não thất 2 bên.

Chụp cắt lớp đa dãy (25/11/2019): Rất nhiều tổn thuơng thứ phát tại các cơ quan gan, phổi, 2 bên, lách, hạch ổ bụng, phần mềm thành bụng trái, khối u lớn giầu mạch kèm các ổ giả phình mạch bên trong thận phải.

8/12 tình trạng tri giác kém hơn, mạch 150, HA 100/60 SPO2 95\%, gia đình xin về và bệnh nhân tử vong trong ngày.

\section{BÀN LUẬN}

Ung thư nguyên bào nuôi có nguồn gốc từ cơ quan sinh dục hay ngoài cơ quan sinh dục, hay gặp nhất ở tử cung liên quan tới thai nghén. Vị trí hay gặp nhất ngoài tử cung là ở trung thất, buồng trứng và tinh hoàn ${ }^{2,3}$ ung thư nguyên bào nuôi ở dạ dày rất hiếm gặp, có một số giả thuyết về sự hình thành ung thư nguyên bào nuôi nguyên phát ở dạ dày ${ }^{1}$ dựa vào sự giống nhau về mô học của ung thư nguyên bào nuôi: (1) do tế bào mầm sinh dục lạc chỗ trong ổ bụng từ thời kỳ bào thai, (2) do di căn từ tổn thương của tinh hoàn thoái triển, (3) nguồn gốc từ u quái dạ dày, do biệt hóa ngược của tế bào ung thư về mức độ ngoại bì bào thai và tạo nên ung thư nguyên bào nuôi ${ }^{2}$. Cũng theo báo cáo này, kể từ báo cáo đầu tiên từ năm 1905 của
Davidsohn đến báo cáo của Akihiro Kobayashi, takahiro Hasebe, Yasushi Endo năm 2005 chỉ có khoảng 140 bệnh nhân ung thư nguyên bào nuôi nguyên phát ở dạ dày được thông báo bằng y văn tiếng anh. Trong 19 bệnh nhân mà Tsuyoshi Noguchi và cộng sự tổng kết trên y văn từ 1980 - 2002 gồm 9 nam và 10 nư, tuổi trung bình 55 (ít nhất 22, cao nhất 80 tuổi), chỉ có 3 bệnh nhân được chẩn đoán ung thư nguyên bào nuôi trước mổ nhờ sinh thiết, hầu hết bệnh nhân có thời gian sống sau khi chẩn đoán trong vòng 1 năm do ung thư nguyên bào nuôi dạ dày có tính chất ác tính rất cao. ${ }^{2}$ Chẩn đoán ung thư nguyên bào nuôi ở dạ dày thường khó khăn do triệu chứng không đặc hiệu và dấu hiệu của di căn ung thư nguyên bào nuôi rất khác nhau. Theo Zhi Liu và CS, ${ }^{4}$ triệu chứng ung thư nguyên bào nuôi ở dạ dày tương tự như ung thư biểu mô dạ dày như đau trên rốn, chán ăn, gầy sút, buồn nôn hay nôn. Triệu chứng chảy máu tiêu hóa trên thường gặp, có thể kèm triệu chứng của nội tiết như chứng vú to, dậy thì sớm hay nôn như nghén. Cả nội soi và chụp cắt lớp vi tính đều thấy có khối ở thành dạ dày, sinh thiết thường khẳng định được tính chất ác tính. Chẩn đoán có thể xác định được khi khối u ở vị trí sinh thiết được. Theo Fang Jiang, Yang Xiang và Feng - Zhi Feng ${ }^{3}$, 8\% ung thư nguyên bào nuôi ở dạ dày được chẩn đoán nhờ sinh thiết nhiều mảnh, $\beta$ - HCG có giá trị chẩn đoán rất quan trọng với tỷ lệ tăng chiếm $96,4 \%$. Tuy nhiên, xét nghiệm này hầu như không được làm ở nam giới trên các y văn từng thông báo. Bệnh nhân của chúng tôi cũng chỉ được làm hồi cứu sau mổ cho thấy tỷ lệ $\beta$ HCG tăng cao tới 21,2 mlU/mL.

Bệnh nhân mà chúng tôi gặp tuổi cao 84 , có tiền sử tai biến mạch não, bệnh lý nền nhiều, đã được chẩn đoán ung thư dạ dày di căn gan, phổi à não sau khi đã được thăm khám tỉ mỉ một cách hệ thống cả về lâm sàng, chẩn đoán 
hình ảnh, nội soi ống tiêu hóa và sinh thiết tổn thương giải phẫu bệnh của $u$ ở dạ dày mà không chẩn đoán được ung thư nguyên bào nuôi ở dạ dày và khó khăn trong chẩn đoán ở bệnh nhân mà chúng tôi gặp tương tự y văn thông báo, nhất lại là ung thư nguyên bào nuôi ở dạ dày của nam giới rất hiếm gặp..$^{1,3,4}$ Có thể phát hiện ung thư nguyên bào nuôi trước mổ nếu sinh thiết lấy nhiều mảnh ở nhiều vị trí của tổn thương ở dạ dày. ${ }^{3}$ Chính vì chẩn đoán khó nên bệnh phát hiện ở giai đoạn muộn không còn khả năng điều trị triệt căn. Khi điều trị chăm sóc giảm nhẹ tại nhà, do bị chảy máu tiêu hóa trên kéo dài từ u dạ dày bệnh nhân đã vào lại bệnh viện và được nội soi lại đường tiêu hóa thấy có tổn thương lồi vào trong lòng dạ dày có cục máu đông bám bề mặt và chụp cắt lớp vi tính thấy có dày thành dạ dày không đều hướng tới u đã thâm nhiễm rộng mà không phát hiện được trên nội soi tiêu hóa và cũng không phát hiện được u ruột non. Do bệnh nhân già yếu, với mục tiêu cầm máu do khối u ở dạ dày chảy máu bệnh nhân đã được mổ cắt u dạ dày hình chêm và sinh thiết nhân di căn như trình bày ở trên. Sau mổ bệnh nhân lại bị chảy máu tiêu hóa và đã phát hiện được 1 khối u ở đoạn cuối hồi tràng nên đã vào viện và được mổ cắt u cầm máu. Chẩn đoán ung thư nguyên bào nuôi ở dạ dày chỉ được xác định nhờ giải phẫu bệnh sau mổ khối u di căn gan, u nguyên phát ở ống tiêu hóa và $\beta$ - HCG tăng cao. Sau mổ tình trạng bệnh nhân đã tiến triển tốt hơn, các chỉ số xét nghiệm huyết học được cải thiện, bệnh nhân tỉnh táo ăn uống tốt hơn. Khoảng 1 tháng sau mổ, bệnh nhân diễn biến xấu vào lại viện vì tình trạng liệt, lơ mơ do khối u di căn não tiến triển, điều trị không kết quả, gia đình xin về và bệnh nhân tử vong trong ngày.

Ung thư nguyên bào nuôi vị trí ở ống tiêu hóa của nam giới là một bệnh rất hiếm gặp, chẩn đoán khó nhất là khi đến muộn có di căn ở nhiều tạng ở người cao tuổi nên chỉ điều trị được triệu chứng chảy máu của khối u ống tiêu hóa. Bệnh nhân sống được 1 tháng sau mổ cũng tương tự như thông báo của y văn. ${ }^{1-4}$ Nếu phát hiện sớm còn khả năng cắt bỏ hoàn toàn khối u nguyên phát và di căn cũng như còn điều trị được hóa chất, hy vọng sẽ kéo dài được thời gian sống cho bệnh nhân. 1,2,5 Theo Fang Jiang, Yang Xiang, Feng - Zhi Feng phẫu thuật triệt căn cắt bỏ ung thư nguyên bào nuôi đóng vai trò quan trọng trong điều trị, điều trị hóa chất sau mổ là cẩn thiết để cải thiệt chất lượng sống và thời gian sống sau mổ ung thư nguyên bào nuôi. Theo dõi $\beta$ - HCG sau mổ để đánh giá hiệu quả điều trị.

\section{KÉT LUẬN}

Ung thư nguyên bào nuôi ống tiêu hóa (dạ dày) ở nam giới rất hiếm gặp, tiên lượng rất xấu. Điều trị phẫu thuật cắt bỏ khối u nguyên phát ở dạ dày và di căn kết hợp với điều trị hóa chất hay cắt bỏ khối u có biến chứng giúp cải thiện tiên lượng.

\section{Lò̀i cảm ơn}

Xin chân thành cảm ơn tới gia đình bệnh nhân và các cán bộ nhân viên Bệnh viện, đặc biệt ở các Khoa Ngoại tổng hợp, Chẩn đoán hình ảnh, Giải phẫu bệnh, Gây mê giảm đau Bệnh viện Đại học $Y$ Hà Nội đã giúp đỡ chúng tôi trong quá trình thực hiện nghiên cứu này.

\section{TÀI LIẸU THAM KHẢO}

1. Kobayashi A, Hasebe $T$, Endo $Y$, et al. Primary gastric choriocarcinoma: two case reports and a pooled analysis of 53 cases. Gastric Cancer. 2005;8(3):178 - 185. doi:10.1007/s10120 - 005 - 0332 - 9

2. Noguchi $T$, takeno $S$, Sato $T$, takahashi Y, Uchida Y, Yokoyama S. A patient with primary gastric choriocarcinoma who received a correct preoperative diagnosis and achieved prolonged 
survival. Gastric Cancer. 2002;5(2):112 - 117. doi:10.1007/s101200200019

3. Jiang F, Xiang Y, Feng F - Z, Ren T, Cui $Z$ - M, Wan X - R. Clinical analysis of 13 males with primary choriocarcinoma and review of the literature. OncoTargets Ther. 2014;7:1135 - 1141. doi:10.2147/OTT.S62561

4. Liu Z, Mira JL, Cruz - Caudillo JC. Primary gastric choriocarcinoma: a case report and review of the literature. Arch Pathol Lab Med.
2001;125(12):1601 - 1604. doi:10.5858/2001 125 - 1601 - PGC

5. Kim G - S, Hwang K - A, Choi K - C. A promising therapeutic strategy for metastatic gestational trophoblastic disease: Engineered anticancer gene-expressing stem cells to selectively target choriocarcinoma (Review). Oncol Lett. 2019;17(3):2576 - 2582. doi:10.3892/ol.2019.9911

\section{Summary \\ GASTROINTESTINAL BLEEDING DUE TO PRIMARY \\ GASTROINTESTINAL CHORIOCARCINOMA (PGC) IN MALE: A CASE REPORT AND REVIEW OF LITERATURE.}

Primary gastrointestinal choriocarcinoma (PGC) is a rare cancer in male. The diagnosis is difficultand the outcome of treatment is limited. We presented a case of a 84 years old male with PGC metastasized to multi organs treated at HMUH by two times emergency surgery over a short period of time because of severe gastrointestinal bleeding; the last hospitalization was for cerebral hemorrhage by PGC metastases with poor prognosis. We presented a review of medical literature of this very rare disease.

Keywords: choriocarcinoma, gastrointestinal tract, male. 